\title{
Changes in semen quality and morphology of the reproductive tract of the male tammar wallaby parallel seasonal breeding activity in the female
}

\author{
D B B P Paris ${ }^{1}$, D A Taggart ${ }^{1,2}$, G Shaw ${ }^{1}$, P D Temple-Smith ${ }^{1}$ and M B Renfree ${ }^{1}$ \\ ${ }^{1}$ Department of Zoology, University of Melbourne, Victoria 3010, Australia and ${ }^{2}$ Royal Zoological Society of \\ South Australia, c/o School of Earth and Environmental Science, University of Adelaide, Frome Road, Adelaide, \\ South Australia 5005, Australia
}

Correspondence should be addressed to M B Renfree; Email: m.renfree@zoology.unimelb.edu.au)

(D B B P Paris is now at Institute of Biomedical and Life Sciences, University of Glasgow, G12 8QQ, UK)

\begin{abstract}
Changes in semen quality and morphology of the male reproductive tract were studied throughout the year in the highly promiscuous tammar wallaby. Body size, semen quality and gross morphology of the reproductive organs were assessed in adult males each month from January to November. The mean weight of males was similar in most periods sampled, but males were slightly heavier in the minor $(\boldsymbol{P}<\mathbf{0 . 0 5})$ than the non-breeding season. Since body weight was correlated with weights of the testes, epididymides and accessory sex glands, organ weights were adjusted for body weight in subsequent analyses. In the major breeding season (late January/early February), when most females go through a brief, highly synchronized oestrus, the testes, prostate, Cowper's glands, crus penis and urethral bulb were heaviest, volume and coagulation of ejaculates were greatest, and sperm motility had increased. Semen samples collected by electroejaculation at this time contained low numbers of spermatozoa, possibly as a result of dilution and entrapment by the seminal coagulum or depletion of epididymal stores during intense multiple mating activity. In the non-breeding season (late May-July), when mating does not normally occur in the wild, there was a significant decrease in the relative weight of nearly all male reproductive organs and a decline in most semen parameters. In the minor breeding season (September-November), when pubertal females undergo their first oestrus and mating, the weights of testes, epididymides and most accessory sex glands had significantly increased similar to those of males in the major breeding season. The total number and motility of ejaculated spermatozoa were highest during this period, but the volume and coagulation of ejaculates and weight of the prostate had only increased to levels that were intermediate between the major and non-breeding seasons. Ejaculate volume was strongly correlated with prostate weight, and \% motile spermatozoa was strongly correlated with epididymis weight. Semen quality thus varied seasonally with changes in androgendependent reproductive organs in the male tammar wallaby and appeared to be influenced by the seasonal timing of oestrus in females. Semen quality may also improve in response to an increase in the number of available oestrous females.

Reproduction (2005) 130 367-378
\end{abstract}

\section{Introduction}

In seasonally breeding mammals, the male reproductive system responds to changes in photoperiod (Hoffmann 1973, Lincoln \& Short 1980, Gemmell 1991, Holloway \& Geiser 1996). In other species, such as the tammar wallaby and kowari, seasonal reproduction in males is controlled by the reproductive status of females (Catling \& Sutherland 1980, Fletcher 1984).

In most seasonally breeding marsupials, circulating testosterone and prostate size increase during the breeding season (Inns 1982, Todhunter \& Gemmell 1987, TyndaleBiscoe \& Renfree 1987, Woolley 1990, Curlewis 1991,
Hamilton et al. 2000). However, patterns of seasonal changes in testis size and spermatogenesis vary. In the brushtail possum (Trichosurus vulpecula), Virginian opossum (Didelphis virginiana), Northern brown bandicoot (Isoodon macrourus), the white-belly opossum (Didelphis albiventris) and the Southern hairy-nosed wombat (Lasiorhinus latifrons) there is no seasonal change in testes size or spermatogenesis (Gilmore 1969, Winegarner 1982, Todhunter \& Gemmell 1987, Nogueira 1988, Taggart et al. 2005). Conversely, in the ringtail possum (Pseudocheirus peregrinus), greater glider (Petauroides volans), feathertail glider (Acrobates pygmaeus) and stripe-face dunnart 
(Sminthopsis macroura), testicular regression occurs in the non-breeding season and spermatogenesis is reduced or arrested (Hughes et al. 1965, Smith 1969, Ward \& Renfree 1988, Taggart et al. 1997).

Only one previous study (Taggart et al. 2005) has reported seasonal changes in semen characteristics in any marsupial. In the Southern hairy-nosed wombat and in many eutherian species, season has a distinct influence on semen volume and quality. Seasonal variation in these characteristics is positively correlated with plasma testosterone levels and the size of testes and accessory glands (Mickelsen et al. 1981, Brown et al. 1991, Monfort et al. 1993, Swanson et al. 1996, Smith et al. 1999, Ciereszko et al. 2000, Goeritz et al. 2003). Thus, high quality semen is associated with increased circulating testosterone and enlarged testes and accessory sex glands during the breeding season.

The tammar wallaby (Macropus eugenii) is a seasonally breeding macropodid marsupial in which over $80 \%$ of females give birth and undergo postpartum oestrus synchronously during the major breeding season in late January/early February (Renfree \& Tyndale-Biscoe 1973, Flint \& Renfree 1982). Within $1 \mathrm{~h}$ of birth, oestrous females mate with multiple competing males (Renfree et al. 1989, Rudd 1994a,b) but the resulting embryo remains in diapause for 11 months, reactivating after the summer solstice (late December), so that the subsequent birth occurs in the next major breeding season. Female offspring born in January/February leave the pouch permanently in October/November (spring). A second minor period of mating occurs at this time when these females enter their first oestrus (Williams et al. 1998) but births in these females are delayed by seasonal diapause until January/February.

In male tammars, luteinizing hormone (LH) and testosterone change seasonally, with an abrupt increase about 2 weeks before mating at a time coinciding with mid pregnancy and the start of the first follicular phase of the new breeding season (Catling \& Sutherland 1980, Flint \& Renfree 1982). However, testosterone remains unchanged in males isolated from females (Catling \& Sutherland 1980) or exposed to cycling females after olfactory bulbectomy (McConnell et al. 1984). This suggests that the seasonal changes in males may be mediated by pheromones (McConnell et al. 1984) associated with increases in progesterone and oestradiol in females shortly after the summer solstice (Flint \& Renfree 1982, Tyndale-Biscoe \& Renfree 1987).

Prostate and Cowper's gland weights increase significantly during the major breeding season in the tammar and a smaller, but significant, rise in testosterone concentration and prostate weight occurs in October/November during the minor breeding season in the wild (Inns 1982). However, the weight of testes and epididymides and the diameter of the seminiferous tubules remain unchanged (Inns 1982) and, as in most macropodids, spermatogenesis and fertile mating can occur year round (Hearn 1975, Inns
1982, Tyndale-Biscoe \& Renfree 1987). However, the effects of seasonal changes in the male reproductive tract on the quality and quantity of spermatozoa and seminal plasma have not been examined. The aim of this study was, therefore, to investigate seasonal changes in semen quality in relation to changes in the weight of testes, epididymides and accessory glands.

\section{Materials and Methods}

\section{Animals}

One hundred and fifty-six reproductively mature male tammar wallabies (Macropus eugenii) with a body weight $>5 \mathrm{~kg}$ or head length $>109 \mathrm{~mm}$ (Inns 1982, Rudd 1994a) were used in this study, of which 126 were caught in the wild (Kangaroo Island, SA, Australia) and 30 were from a captive colony maintained under natural seasonal conditions in Wantirna, Vic., Australia (Table 1). Seventy-one males were directly sampled during 2000 and 2001. Additional data from 1993 to 2005 were obtained from records kept of males shot in the wild for other studies $(n=57)$, and from males used for semen collection in artificial insemination experiments during 2001 to 2003 $(n=28)$ (Paris et al. 2005). Body weight, head length, pes length and scrotal width of males were measured as previously described (Rudd 1994a), semen samples were collected and their reproductive tracts dissected. Plasma testosterone was not assessed in this study because extensive handling of male macropodids (as required for semen collection) causes a rapid decline in plasma testosterone concentration (Lincoln 1978). Samples were collected in January and February (major breeding season), March and April (post-major breeding season), May, June and July (non-breeding season) and September, October and November (minor breeding season). Additionally, semen samples were collected on more than one occasion during the year from seven captive males.

Males were anaesthetized with an intra-muscular dose of tiletamine and zolazepam (50 mg Zoletil 100; Virbac Pty. Ltd, Peakhurst, NSW, Australia) and maintained with $2-5 \%$ isoflurane (Abbott Australasia Pty. Ltd, Kurnell, NSW, Australia) in 1 litre/min oxygen for semen collection and then killed by intra-cardiac injection of $16 \mathrm{ml}$ sodium pentobarbitone $(60 \mathrm{mg} / \mathrm{ml}$; Abbott Australasia Pty. Ltd). All experiments were approved by the Animal Experimentation Ethics Committees of the University of Melbourne.

\section{Semen collection and assessment}

Semen $(n=70)$ was collected by electroejaculation (Paris et al. 2005) in all breeding seasons (Table 1). In an effort to prevent coagulation of semen post-ejaculation, samples were collected directly into sterile $50 \mathrm{ml}$ conical tubes (Becton Dickinson Labware, Franklin Lakes, NJ, USA) containing $10 \mathrm{ml}$ pre-warmed $\left(35^{\circ} \mathrm{C}\right)$ Dulbecco's modified Eagles' media containing $20 \mathrm{mM}$ 
Table 1 Size and reproductive parameters (mean \pm S.E.M.) of male tammar wallabies sampled across the four breeding seasons categories defined in this study. Values in parentheses indicate sample size.

\begin{tabular}{|c|c|c|c|c|}
\hline \multirow[b]{2}{*}{ Parameter } & \multicolumn{4}{|c|}{ Breeding season } \\
\hline & Major & Post-major & Non- & Minor \\
\hline Nos (wild; colony) & $74 ; 0$ & $3 ; 23$ & $12 ; 7$ & $37 ; 0$ \\
\hline Year & 1993/1998/2000/2001/2005 & $2001 / 2002 / 2003 / 2005$ & $2000 / 2002 / 2005$ & $2000 / 2001$ \\
\hline Months & Jan-Feb & Mar-Apr & May-Jul & Sep-Nov \\
\hline Body weight (kg) & $6.8 \pm 0.1^{\mathrm{AB}}(74)$ & $6.5 \pm 0.2^{\mathrm{AB}}(25)$ & $6.4 \pm 0.3^{\mathrm{B}}(19)$ & $7.3 \pm 0.2^{\mathrm{A}}(37)$ \\
\hline Head length (mm) & $114.0 \pm 0.8(25)$ & $111.1 \pm 1.0(20)$ & $113.6 \pm 1.0(17)$ & $112.5 \pm 0.6(37)$ \\
\hline Pes length $(\mathrm{mm})$ & $152.0 \pm 1.1(22)$ & $150.4 \pm 0.4(2)$ & $151.1 \pm 1.3(12)$ & $152.4 \pm 0.7(37)$ \\
\hline Samples collected & $\mathrm{S}, \mathrm{T}$ & $\mathrm{S}$ & $\mathrm{S}, \mathrm{T}$ & $\mathrm{S}, \mathrm{T}$ \\
\hline Testis* (g) & $16.4 \pm 05(44)$ & Not done & $12.5 \pm 1.0(15)$ & $16.8 \pm 0.5(32)$ \\
\hline Epididymis* (g) & $3.3 \pm 0.2(24)$ & Not done & $3.2 \pm 0.3(11)$ & $3.8 \pm 0.1(32)$ \\
\hline Scrotal width* (mm) & $61.7 \pm 0.7(41)$ & $55.9 \pm 2.9(3)$ & $52.8 \pm 1.6(16)$ & $61.3 \pm 0.7(34)$ \\
\hline Prostate* $(\mathrm{g})$ & $79.5 \pm 5.5(31)$ & Not done & $15.2 \pm 1.8(14)$ & $31.0 \pm 3.2(34)$ \\
\hline Cowper's gland $1 *(\mathrm{~g})$ & $0.51 \pm 0.05(10)$ & Not done & $0.20 \pm 0.02(9)$ & $0.43 \pm 0.03$ \\
\hline Cowper's gland $2 *(\mathrm{~g})$ & $1.7 \pm 0.1(10)$ & Not done & $0.7 \pm 0.1(11)$ & $1.4 \pm 0.1$ \\
\hline Cowper's gland $3 *(\mathrm{~g})$ & $1.0 \pm 0.1(10)$ & Not done & $0.6 \pm 0.1(11)$ & $0.9 \pm 0.05(34)$ \\
\hline Crus penis* (g) & $5.7 \pm 0.3(10)$ & Not done & $3.5 \pm 0.4(7)$ & $5.3 \pm 0.1(34)$ \\
\hline Urethral bulb* (g) & $2.9 \pm 0.2(10)$ & Not done & $1.5 \pm 0.2(11)$ & $2.8 \pm 0.1(34)$ \\
\hline
\end{tabular}

${ }^{\mathrm{A}, \mathrm{B}}$ Values not sharing the same letter within rows (body weight, head length and pes length) were significantly different $(P<0.05)$.

$\mathrm{S}$, semen; $\mathrm{T}$, reproductive tract.

* Absolute values (before ANCOVA seasonal comparison using body weight as a co-variate).

HEPES and $4.5 \mathrm{~g} / \mathrm{l}$ glucose (Thermo Trace Ltd, Noble Park, Vic., Australia) supplemented with $4 \%(\mathrm{v} / \mathrm{v})$ fetal bovine serum (FBS) and $50 \mathrm{IU} / \mathrm{ml}, 50 \mu \mathrm{g} / \mathrm{ml}$ penicillin and streptomycin (Pen/Strep; both from Thermo Trace Ltd), or Earle's minimal essential media containing 25 mM HEPES (Invitrogen Corp., Mulgrave, Vic., Australia) supplemented with $4 \%(\mathrm{v} / \mathrm{v}) \mathrm{FBS}$ and $50 \mathrm{IU} / \mathrm{ml}$, $50 \mu \mathrm{g} / \mathrm{ml}$ Pen/Strep.

Ejaculate volumes were measured, and coagulation (which did occur in the presence of media) was assessed using a $0-3$ scale where $0=$ no coagulation/complete mixing with media and $3=$ solid plug formation/no mixing with media. Samples were maintained at $35^{\circ} \mathrm{C}$ for 10 min to allow spermatozoa to migrate from the plug (if present) into the medium fraction. The medium fraction was then assessed for $\%$ motile spermatozoa, motility rating $(0-4$ scale), sperm motility index (0-400 scale), and concentration and total number of spermatozoa in the ejaculate (Paris et al. 2005).

\section{Collection and measurement of reproductive tracts and effects of fixation}

Male reproductive tracts $(n=95)$ were collected in all seasons except the post-major breeding season (Table 1). Testes and epididymides were dissected free of the scrotal sac and tunica vaginalis, and the remaining parts of the reproductive tract were removed within 10 min of death (Fig. 1). All testes and epididymides were fixed for 1 week in Bouin's fixative (Hopwood 1990) before being transferred to $70 \%(\mathrm{v} / \mathrm{v})$ ethanol. Prostates, Cowper's glands, urethral bulbs and crus penis were fixed in $10 \%(\mathrm{v} / \mathrm{v})$ neutral buffered formalin (NBF), except for ten of 19 samples from the non-breeding season that were fixed in Bouin's fixative.
All reproductive organs were dissected and weighed individually after fixation and, in the case of paired organs (testes, epididymides, three Cowper's glands, crus penis and urethral bulb; Fig. 1), the mean weight was used in subsequent analyses. In order to determine the extent of shrinkage after fixation, the prostate and each testis still attached to the epididymis was weighed fresh and again after fixation from samples collected in January, October and November. Prostate weight (fresh $52.6 \pm 6.0 \mathrm{~g}$ vs fixed $48.8 \pm 5.5 \mathrm{~g}$; both $n=26)$ was reduced by $6.3 \pm 1.0 \%(n=26)$ after fixation in $10 \%$ NBF and the weight of the testis still attached to the epididymis (fresh $23.4 \pm 0.6 \mathrm{~g}$ vs fixed $20.5 \pm 0.5 \mathrm{~g}$; both $n=33$ ) was reduced by $12.2 \pm 0.2 \%(n=33)$ after fixation in Bouin's fixative. Fresh and fixed weights were highly correlated for both the prostate and testis still attached to the epididymis (both $r=0.997 ; P<0.001 ; n=31$ and $n=33$ respectively), hence only fixed organ weights were used for subsequent analyses (Fig. 3). To enable a comparison between prostates, Cowper's glands, urethral bulbs and crus penis fixed in Bouin's fixative (ten samples from the non-breeding season) and those fixed in 10\% NBF (all other months), the weight of Bouin's fixed organs was corrected to NBF weights by conversion to the original fresh organ weights, then to NBF weights using the mean \% weight reduction rates above.

\section{Statistical analyses}

Values are presented as means \pm S.E.M. Raw data were analysed for normal distribution, equal variance and the presence of outliers (Quinn \& Keough 2002). Data for prostate weight, ejaculate volume, sperm concentration and total number of spermatozoa were $\log _{10}$ transformed 


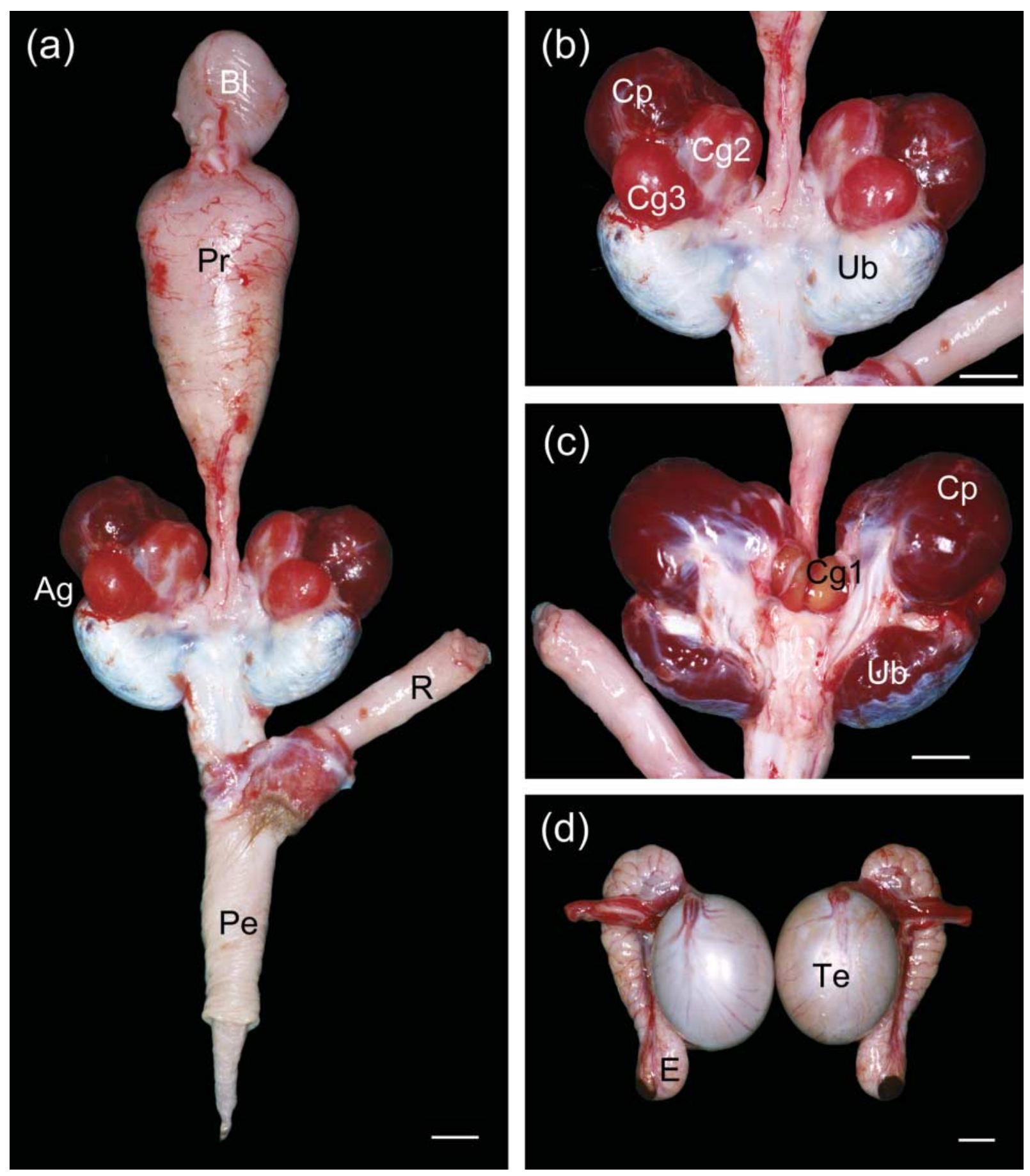

Figure 1 Anatomy of the reproductive tract of the male tammar wallaby. (a) Dorsal view of whole tract, (b) dorsal and (c) ventral view of accessory glands, and (d) testes and epididymides. Ag, accessory glands; Bl, bladder; Cg, Cowper's gland; Cp, crus penis; E, epididymis; Pe, penis; Pr, prostate; $R$, rectum; Te, testis; Ub, urethral bulb. Scale bars, $1 \mathrm{~cm}$.

and $\%$ motile spermatozoa and motility rating were reflected then $\log _{10}$ transformed to normalize the sample data (Quinn \& Keough 2002). Parameters were grouped into major breeding season (January/February), post-major breeding season (March/April), non-breeding season (May/June/July) and minor breeding season (September/ October/November).
Before comparisons, each parameter was tested for a relationship with body weight. Differences in each parameter between captive and wild animals within each season were compared and, as differences were not significant, data from captive and wild animals were pooled. Differences between breeding seasons were then compared. Unbalanced analysis of covariance (ANCOVA) 
using body weight as a co-variant was used for comparisons in those parameters in which a significant relationship with body weight was detected. Unbalanced ANOVA was used for comparisons in all other parameters. Where relevant, the body weight adjusted mean for each parameter for each season was obtained from the adjusted least squares mean of the ANCOVA output based on the formula (Quinn \& Keough 2002):

$$
\mu_{i(a d j)}=\bar{y}_{i}-b\left(\bar{x}_{i}-\bar{x}\right)
$$

The standard error of the adjusted means was calculated manually based on the formula (Quinn \& Keough 2002):

$$
S_{y_{\text {i(adj) }}}=\sqrt{M S_{\text {residual }}\left(\frac{1}{n_{i}}+\frac{\left(\bar{x}_{i}-\bar{x}\right)^{2}}{S S_{\text {residual(x) }}}\right)}
$$

Where $i$ is the breeding season (major, post-major, nonand minor); $\bar{y}_{i}$ is the mean of each parameter for group $i$; $\bar{x}_{i}$ is the mean body weight for group $i ; \bar{x}$ is the mean body weight for the total samples; $b$ is the estimate of the within-group regression co-efficient relating $\mathrm{Y}$ to $\mathrm{X}$; $M S_{\text {residual }}$ is the mean square of the error term from the ANCOVA output; and $S S_{\text {residual }(x)}$ is the sum of squares of the error term from a separate ANOVA on body weight.

Relationships between different parameters were tested by pair-wise Pearson correlations (or pair-wise Spearman correlations for coagulation rating and motility rating). Significance was determined with post hoc pair-wise Bonferroni tests, except for Spearman correlations in which $r<0.3$ was considered unrelated (Quinn \& Keough 2002). Post hoc pair-wise Tukey's tests were used for breeding season comparisons. Probabilities $<0.05$ were considered to be significant. Analyses were conducted using SYSTAT 9.01 software (Systat Software Inc., Point Richmond, CA, USA).

\section{Results}

\section{Size of males}

Mean head length $(112.8 \pm 0.4 \mathrm{~mm} ; n=99)$ and pes length $(152.0 \pm 0.5 \mathrm{~mm} ; n=73)$ of adult males did not differ significantly over the sample period (Table 1). For body weight (overall mean $6.8 \pm 0.1 \mathrm{~kg} ; n=155$ ) there was a small but significant difference between animals sampled in the minor and non-breeding seasons (Table 1). To correct for this, ANCOVA with body weight as a co-variate was used for comparisons in those parameters in which a significant body weight relationship was detected.

\section{Relationship between body weight and morphology of the reproductive organs}

Body weight was significantly correlated with the weight of the reproductive organs including the testis $(r=0.591$; $n=92)$, epididymis $(r=0.669 ; n=67)$, Cowper's glands $1(r=0.406 ; n=53)$ and $2(r=0.267 ; n=55)$, crus penis $(r=0.582 ; n=51)$ and urethral bulb $(r=0.394$; $n=55)$, and also with scrotal width $(r=0.524 ; n=94)$. Prostate weight was only significantly correlated with body weight in the minor breeding season $(r=0.342$; $n=34)$. Body weight was not correlated with Cowper's gland 3 weight or any semen parameters $(P>0.05)$.

\section{Seasonal changes in semen}

All semen parameters had a significant seasonal variation, with the lowest values generally during the non-breeding season (Fig. 2). Ejaculate volumes were significantly larger during the major breeding season $(8.9 \pm 1.2 \mathrm{ml})$ than all other seasons and were intermediate between major and non-breeding volumes during the minor breeding season $(5.0 \pm 0.7 \mathrm{ml})$. The ejaculate had a significantly higher coagulation rating during the major and post-major breeding seasons (both $2.0 \pm 0.2$ ) than in the non-breeding season $(0.8 \pm 0.4)$. The concentration of spermatozoa was lowest in the major and post-major breeding seasons $\left(45.3 \pm 14.3 \times 10^{6}\right.$ and $62.2 \pm 14.0 \times 10^{6}$ spermato$\mathrm{zoa} / \mathrm{ml}$ ) and increased significantly in the minor breeding season $\left(375.5 \pm 176.8 \times 10^{6}\right.$ spermatozoa $\left./ \mathrm{ml}\right)$. The total number of spermatozoa ejaculated had a similar seasonal pattern; however, sperm numbers in the minor breeding season (1028.0 $\pm 229.0 \times 10^{6}$ sperm per ejaculate) were significantly higher than all other seasons. The \% motile spermatozoa was significantly higher in the post-major and minor breeding seasons $(91.5 \pm 2.1$ and $94.2 \pm 1.0 \%)$ than the non-breeding season $(77.0 \pm 5.0 \%)$. Motility rating was significantly higher in the minor breeding season $(3.8 \pm 0.1)$ than all other seasons, while the sperm motility index was significantly higher in the major and minor breeding seasons $(255.1 \pm 7.2$ and $303.9 \pm 8.9)$ than the non-breeding season $(192.9 \pm 23.9)$.

Ejaculate volume and coagulation rating were positively correlated $(r=0.413 ; n=70)$ and both were negatively correlated with sperm concentration $(r=-0.313$ and -0.374 ; both $n=67$ ). As expected, sperm concentration and total sperm number had a strong positive correlation $(0.862 ; n=67)$, and both were positively correlated with motility rating $(r=0.496$ and 0.519 respectively; both $n=67)$ and sperm motility index $(r=0.375$ and 0.440 respectively; both $n=65$ ) but not $\%$ motile spermatozoa $(P>0.05)$. Similarly, \% motile spermatozoa was positively correlated with motility rating $(r=0.340 ; n=65)$ and sperm motility index $(r=0.556 ; n=65)$, and motility rating and sperm motility index were strongly correlated $(r=0.817 ; n=65)$.

\section{Seasonal changes in reproductive organs}

Reproductive tracts were not collected in the post-major breeding season and all organs that had a significant correlation with body weight were adjusted for body weight. All male reproductive organs varied significantly across breeding seasons, with the lowest values during the 

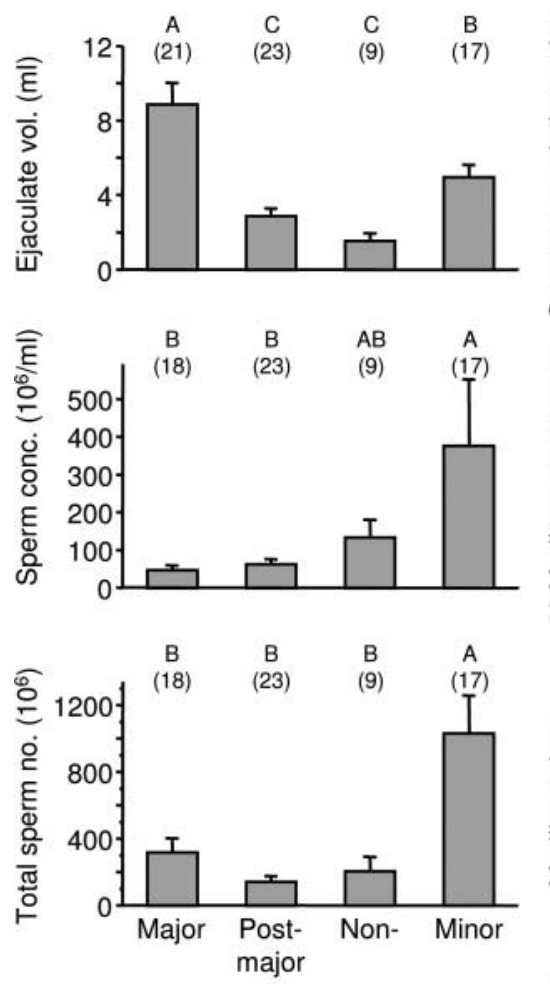

Breeding season
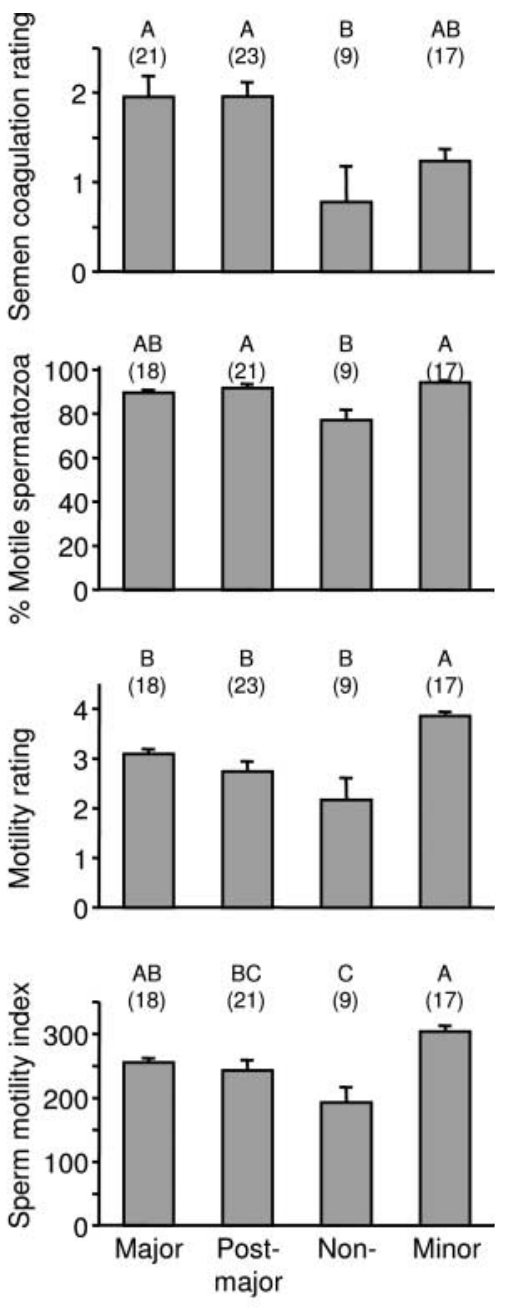

Breeding season
Figure 2 Changes in semen quality (means \pm S.E.M.) across the major (January/February), post-major (March/April), non- (May-July) and minor (September-November) breeding seasons in male tammar wallabies. Parameters include ejaculate volume, sperm concentration, total number of spermatozoa ejaculated, semen coagulation rating, \% motile spermatozoa, motility rating and sperm motility index. $A, B$ and $C$, values not sharing the same letter within each graph were significantly different $(P<0.05)$. The number of males is shown in parentheses. non-breeding season (Fig. 3). The weights of the testis and epididymis as well as the scrotal width were significantly lower in the non-breeding season $(13.3 \pm 0.7 \mathrm{~g}, 3.2 \pm 0.2 \mathrm{~g}$ and $54.0 \pm 1.1 \mathrm{~mm}$ respectively) than the minor (16.2 $\pm 0.5 \mathrm{~g}, 3.7 \pm 0.1 \mathrm{~g}$ and $60.6 \pm 0.7 \mathrm{~mm}$ respectively) and also, for testis weight and scrotal width, the major $(16.7 \pm 0.4 \mathrm{~g}$ and $61.8 \pm 0.7 \mathrm{~mm}$ respectively) breeding seasons. The greatest seasonal change was seen in the prostate, where there was a fivefold change in average weight between the non-breeding season $(14.7 \pm 2.1 \mathrm{~g})$ and the main breeding season $(74.5 \pm 6.6 \mathrm{~g})$. Prostate weight was intermediate in the minor breeding season $(25.6 \pm 2.2 \mathrm{~g})$. Cowper's glands 1, 2, 3 and urethral bulb weights had similar seasonal changes, being significantly lighter in the nonbreeding season $(0.22 \pm 0.04,0.8 \pm 0.1,0.6 \pm 0.1$ and $1.6 \pm 0.2 \mathrm{~g}$ respectively) than the major $(0.52 \pm 0.04$ $1.7 \pm 0.1,1.0 \pm 0.1$ and $3.0 \pm 0.2 \mathrm{~g}$ respectively) and minor $(0.42 \pm 0.02,1.4 \pm 0.1,0.9 \pm 0.05$ and $2.8 \pm 0.1 \mathrm{~g}$ respectively) breeding seasons. The crus penis was significantly heavier in the major breeding season $(5.8 \pm 0.2 \mathrm{~g})$ than all other seasons and was intermediate in weight during the minor breeding season (5.2 $\pm 0.1 \mathrm{~g}$ ).

Testis weight was significantly correlated with scrotal width $(r=0.909 ; n=69)$ and the weights of all male reproductive organs including the epididymis $(r=0.789$; $n=67)$, prostate $(r=0.489 ; n=77)$, Cowper's glands 1 , $2,3(r=0.571,0.583$ and $0.656 ; n=51,53$ and 53 respectively), crus penis $(r=0.689 ; n=49)$ and urethral bulb $(r=0.583 ; n=53)$.

\section{Relationship between semen and reproductive organ parameters}

With the exception of Cowper's gland 2, both ejaculate volume and coagulation rating were positively correlated with testis, epididymis, prostate and Cowper's gland weights (Table 2). Ejaculate volume was most strongly correlated with prostate weight. In contrast, sperm concentration had the strongest negative correlation with prostate weight and was also negatively correlated with the weights of Cowper's glands 1 and 3. The \% motile spermatozoa was positively correlated with the weight of all 

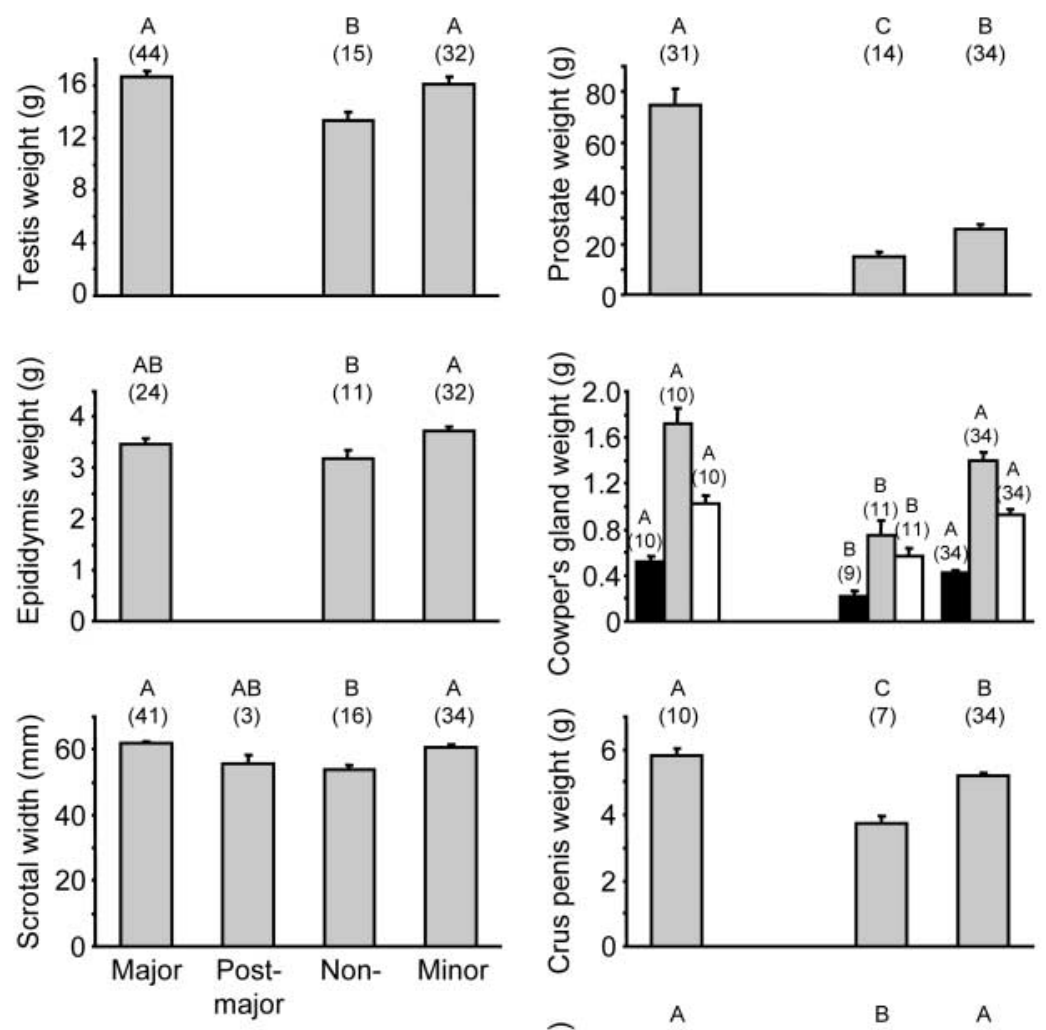

Breeding season
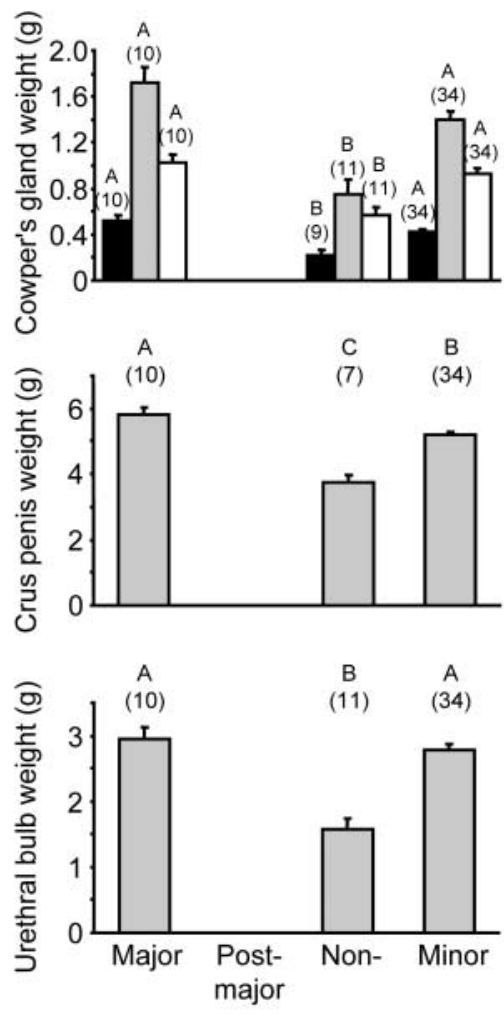

Breeding season
Figure 3 Changes in the reproductive tract (means \pm S.E.M.) across the major (January/February), post-major (March/April), non- (May-July) and minor (September-November) breeding seasons in male tammar wallabies. Parameters $\left({ }^{\dagger}\right.$ adjusted for body weight) include testis weight ${ }^{\dagger}$, epididymis weight $^{\dagger}$, scrotal width ${ }^{\dagger}$, prostate weight ${ }^{\dagger}$, Cowper's glands $1^{\dagger}$ (solid bars), $2^{+}$(shaded bars) and 3 (open bars) weight, crus penis weight ${ }^{\dagger}$ and urethral bulb weight $^{\dagger}$. A, B and C, values not sharing the same letter within each organ were significantly different $(P<0.05)$. The number of males is shown in parentheses. reproductive organs, but most strongly with epididymis weight. Total sperm number, motility rating and sperm motile index were not correlated with the weights of any reproductive organs.

\section{Discussion}

This study has shown that seasonal changes occur in most semen parameters in parallel with seasonal changes in the weight of the reproductive organs, with highest values during the breeding seasons and lowest values during the non-breeding season in the male tammar wallaby. However, sperm concentration was lowest and total number of ejaculated spermatozoa was low in the major breeding season when all other parameters were greatest. The reason for this unexpected reduction in sperm output is not clear but may be influenced by dilution in large volumes of seminal fluid and entrapment in strongly coagulated ejaculates that are present at this time. The weights of the prostate and epididymis were most strongly correlated with ejaculate volume and \% motile spermatozoa respectively. Changes in semen quality and morphology of the male reproductive tract parallel the seasonal breeding activity in the female and may reflect the number of available oestrous females or level of intermale pre- and post-copulatory competition.

Spermatogenesis is generally regarded as continuous in macropodids (Tyndale-Biscoe \& Renfree 1987), and tammar spermatozoa are motile year round (Hearn 1975), a finding confirmed by our study. However, we found the proportion of motile spermatozoa and their motility rating increased significantly during the times of year when breeding occurred. This was associated with increased weight of all reproductive organs, as well as increased sperm number and concentration observed in the minor breeding season. As in other mammals, spermatozoa acquire the capacity for motility in the epididymis in the tammar (Jones et al. 1984, 1988, Jones 1989) and motility increases as the number of structurally mature spermatozoa increase in the corpus and caudal regions (Jones et al. 


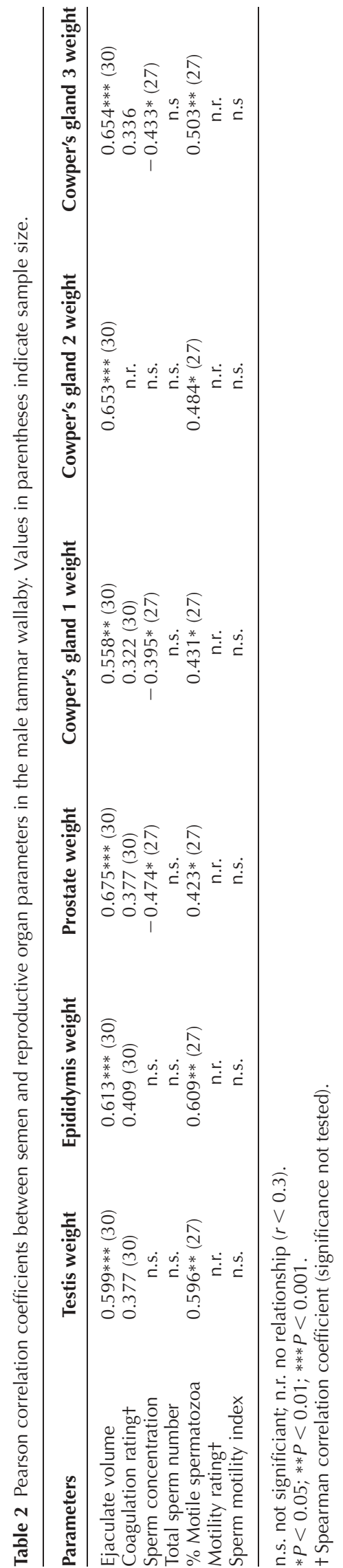

1984). In many seasonally breeding eutherians, increased testosterone levels and testis and epididymis size in the breeding season are accompanied by improved sperm morphology and increased sperm motility (Mickelsen et al. 1981, Brown et al. 1991, Monfort et al. 1993, Smith et al. 1999, Goeritz et al. 2003). Thus, in the tammar it is likely that elevated testosterone in the breeding season(s) results in an increase in the proportion of functionally mature and highly motile spermatozoa. In addition, there is an androgen-dependent increase in the volume and concentration of macropodid accessory sex gland secretions in the seminal plasma that provide an energy source for sperm metabolism and motility (Rodger \& Hughes 1973, Hearn 1975, Rodger \& White 1975, Murdoch \& Jones 1998). This may explain the strong correlation observed between $\%$ motile spermatozoa and all reproductive organs examined.

Our study found a seasonal variation in testis and epididymis weight and scrotal diameter which is consistent with observed seasonal changes in testosterone and $\mathrm{LH}$ (Catling \& Sutherland 1980). Seasonal change in testis size also occurs in the Bennett's wallaby (Macropus rufogriseus rufogriseus) and musky rat-kangaroo (Hypsiprymnodon moschatus) (Curlewis 1991, Dennis \& Marsh 1997), but was not detected in previous studies in the tammar (Hearn 1975, Inns 1982). These tammar studies, however, did not adjust their analyses to correct for variations in body weight of the males used. Inns (1982) gathered data from sexually mature males shot in the wild with testes ranging from 8 to $27 \mathrm{~g}$. Hearn (1975) used males ranging from 5 to $6.5 \mathrm{~kg}$. Since testis size and body weight are correlated (Harcourt et al. 1981, Kenagy \& Trombulak 1986, this study) and both increase with age in male tammars (Inns 1982), small seasonal variations in organ weight can easily be undetectable because of substantial between-animal variation in body weight unless the data are adjusted accordingly. As seminiferous tubule diameter is unchanged in the tammar (Inns 1982), changes in the size and activity of the Leydig cells (Jones 1989) are the most likely explanation for the seasonal changes in the size of the testis as recorded in the white-belly opossum (Queiroz \& Nogueira 1992) and in the swamp wallaby (J Paplinska, unpublished observations). Further studies are needed to confirm this histologically.

Ejaculates were largest and had the highest coagulation rating during the major breeding season in our study when all male reproductive organs were heaviest. By the non-breeding season, ejaculate volume had decreased sixfold and prostate weight had decreased fivefold. Both then rose to intermediate levels in the minor breeding season. This strong correlation is explained by the fact that in macropodids the prostate gland contributes the bulk of the seminal plasma and the prostatic bodies that cause coagulation (Rodger \& Hughes 1973, Rodger \& White 1975, Tyndale-Biscoe \& Rodger 1978) and prostate weights vary seasonally in the tammar, Bennett's and swamp wallabies (Inns 1982, Curlewis 1991, J Paplinska, unpublished 
observations). Likewise, in roe deer and the Southern hairy-nosed wombat, ejaculate volume and prostate size are also greatest during the time of peak sexual activity (Goeritz et al. 2003, Taggart et al. 2005).

Semen production and output in mammals is influenced by a variety of factors, including testis size and spermatogenic activity, storage capacity of the epididymis, frequency of ejaculation and depletion of sperm stores, and change in the fluid volume of the ejaculate. The low concentration and total numbers of ejaculated tammar spermatozoa during the major breeding season may be due to a combination of dilution, coagulation and possibly depletion of spermatozoa. Sperm dilution occurs during the breeding season in the pig, another species that produces large ejaculate volumes (Ciereszko et al. 2000). Thus, the dramatic increase in accessory sex organ weights in the major breeding season relative to the nonbreeding season and associated sixfold increase in ejaculate volume may account for the threefold decrease in sperm concentration in the ejaculate.

However, the low total numbers of spermatozoa at this time, when ejaculates are most coagulated, suggest other factors are also involved. In macropodids, semen coagulates to form a copulatory plug which is thought to be a barrier in the female reproductive tract to the migration of spermatozoa from rival males (Tyndale-Biscoe \& Rodger 1978, Taggart et al. 1998). In earlier studies, ejaculated tammar semen coagulated and spermatozoa became entrapped in clumps around the prostatic bodies (Rodger \& White 1975, 1978). Although attempts were made to collect semen directly into media, this did not prevent coagulation of ejaculates in our study. Thus, our method of assessing total numbers of spermatozoa during the major breeding season may have been affected by the coagulum, resulting in an underestimation of the total numbers, since spermatozoa trapped in the plug would not have been counted.

The decrease in sperm numbers detected in the major breeding season may also be due, at least in part, to depletion of epididymal sperm reserves during the intensive period of mating, as reported in other highly promiscuous species (Westneat et al. 1998, Preston et al. 2001). In two other kangaroo species in which semen coagulation occurs, the unusually low numbers of spermatozoa found in ejaculates of larger males were thought to be due to excessive sexual activity or to age-related reduced fertility (Sadleir 1965).

Tammars have a promiscuous mating system, malebiased sexual dimorphism, large relative testis mass, mateguarding behaviour and presence of copulatory plugs, all characteristics typical of species where sperm competition occurs (Huck et al. 1989, Taggart et al. 1998). Larger males have greater paternity success in many species through physically superior competition for access to females for mating or superior fecundity (Huck \& Banks 1982, Gullberg et al. 1997, Fisher \& Lara 1999). The tammar wallaby appears to benefit in both ways. Dominant males tend to be larger, mate first with oestrous females and guard them post-copulation (Renfree et al. 1989, Rudd 1994b) and heavier males have heavier reproductive organs, which in turn are associated with a greater volume and coagulation of ejaculates and a higher proportion of motile spermatozoa (this study). Larger testis size has also been linked to high rates of sperm production in mammals (Harcourt et al. 1981, Kenagy \& Trombulak 1986). However, larger body size, mating first and mate guarding the female are only moderate predictors of paternity success in male tammars (Ewen et al. 1993, Hynes et al. 2005).

In tammars, females may be mated repeatedly and their tracts may contain up to $200 \mathrm{~g}$ coagulated semen resulting from matings by several males (Tyndale-Biscoe \& Rodger 1978, Paris et al. 2004). This large seminal plug is thought to keep spermatozoa in proximity to the cervices, prevent loss from the tract, or provide a barrier to the migration of spermatozoa from other males (Tyndale-Biscoe \& Rodger 1978, Taggart et al. 1998). Recently, the function of the copulatory plug as a sperm reservoir or to prevent sperm loss has been discounted in the tammar (Paris et al. 2004). Although rapid sperm migration to the periphery of the plug in the female reproductive tract has been reported (Tyndale-Biscoe \& Rodger 1978), the plug also appears to entrap sperm (Rodger \& White 1975, 1978, Paris et al. 2004, this study). Thus, the role of the copulatory plug as a sperm competition barrier remains to be determined and will be the subject of further studies.

The major breeding season, in which $>80 \%$ of female tammars undergo postpartum oestrus, is a period of intense competition among males (Renfree \& Tyndale-Biscoe 1973, Flint \& Renfree 1982, Tyndale-Biscoe \& Renfree 1987, Rudd 1994b, M B Renfree \& G Shaw unpublished observations). In our study, this coincided with the greatest volume and coagulation of ejaculates, elevated sperm motility and heaviest male reproductive organs. In the non-breeding season, little or no reproductive activity occurs due to a gradual seasonal inhibition of blastocyst reactivation and postpartum oestrus in adult females until the summer solstice (Tyndale-Biscoe et al. 1974). This period coincides with a significant decline in the weight of nearly all reproductive organs and nearly all semen parameters in the tammar and, like the ram and deer, may represent an energy saving when there is little benefit in maintaining optimal breeding condition (Lincoln \& Short 1980).

Unexpectedly in our study, the concentration and number of spermatozoa ejaculated was highest, but most variable, during the minor breeding season. Androgen levels are lower at this time than seen in the main breeding season (Catling \& Sutherland 1980) and correspondingly the volume and coagulation of ejaculates and weight of the prostate were lower (this study). Thus the negative effects of dilution and coagulation on the measurement of sperm numbers are less evident. Additionally, in contrast to the major breeding season where most matings occur within a 2-week period (Tyndale-Biscoe \& Renfree 1987), the 
minor breeding season is less synchronous. The duration of mating activity may extend for 2-3 months from late September to November and the only females in oestrus at this time of the year are the pubertal females, of which only about half enter oestrus as they reach a minimum body weight $(>2.5 \mathrm{~kg}$ ) (Williams et al. 1998). Since males would be expected to mate less, sperm depletion may occur less frequently.

The seasonal changes in the male tract and the resulting changes in semen appear to occur in response to the female, most likely mediated through pheromones (Catling \& Sutherland 1980, Inns 1982, McConnell et al. 1984, Jackson \& Harder 1996). Anticipated copulation or the presence of oestrous females is known to result in a rise in plasma testosterone (Katongole et al. 1971, Jainudeen et al. 1972, Kamel et al. 1975, Illius et al. 1976), and the presence of unfamiliar, more sexually attractive or more promiscuous female fowl (Gallus gallus) results in an increased number of ejaculated spermatozoa (Pizzari et al. 2003). Changes in semen quality in the tammar may therefore reflect the number of available oestrous females, the level of inter-male competition, or both. Fertile matings can occur year round in the tammar (Tyndale-Biscoe \& Renfree 1987), so males are capable of maintaining a baseline level of fertility that enables them to mate opportunistically at any time of the year. However, individual variation in the ability to increase semen output and sperm quality during both the major and minor breeding seasons in response to the availability of oestrous females may confer an advantage in sperm competition to individual males of this species.

\section{Acknowledgements}

We thank all members of the wallaby research group and in particular John Akamatis, Scott Brownlees, Patrick Jackson and Michael Leihy for assistance with sample collection in the field. Thanks also go to Elizabeth Dalgleish and Mick Keough for statistical advice and Justyna Paplinska for her unpublished observations in the swamp wallaby. This research was supported by a SPIRT grant (No. C09930004) from the Australian Research Council to M B R, G S, P D T-S and Zoos Victoria. D B B P P was supported by a Faculty of Science PhD scholarship from the University of Melbourne. The authors declare that there is no conflict of interest that would prejudice the impartiality of this scientific work.

\section{References}

Brown JL, Wildt DE, Raath JR, de Vos V, Howard JG, Janssen DL, Citino SB \& Bush M 1991 Impact of season on seminal characteristics and endocrine status of adult free-ranging African buffalo (Syncerus caffer). Journal of Reproduction and Fertility 92 47-57.

Catling PC \& Sutherland RL 1980 Effect of gonadectomy, season and the presence of female tammar wallabies (Macropus eugenii) on concentrations of testosterone, luteinizing hormone and follicle-stimulating hormone in the plasma of male tammar wallabies. Journal of Endocrinology 86 25-34.
Ciereszko A, Ottobre JS \& Glogowski J 2000 Effects of season and breed on sperm acrosin activity and semen quality of boars. Animal Reproduction Science 64 89-96.

Curlewis JD 1991 Seasonal changes in the reproductive organs and plasma and pituitary hormone content of the male Bennett's wallaby Macropus rufogriseus rufogriseus. Journal of Zoology 223 223-232.

Dennis AJ \& Marsh H 1997 Seasonal reproduction in musky rat-kangaroos, Hypsiprymnodon moschatus: a response to changes in resource availability. Wildlife Research 24 561-578.

Ewen KR, Temple-Smith PD, Bowden DK, Marinopoulos J, Renfree MB \& Yan H 1993 DNA fingerprinting in relation to male dominance and paternity in a captive colony of tammar wallabies (Macropus eugenii). Journal of Reproduction and Fertility 99 $33-37$.

Fisher DO \& Lara MC 1999 Effects of body size and home range on access to mates and paternity in male bridled nailtail wallabies. Animal Behaviour 58 121-130.

Fletcher TP 1984 The effect of presence of females on seasonal testosterone concentrations in male kowaris, Dasyuroides byrnei. In Proceedings of the 15th Annual Conference of the Australian Society for Reproductive Biology. Melbourne, Australia, Abstract 22.

Flint APF \& Renfree MB 1982 Oestradiol-17 $\beta$ in the blood during seasonal reactivation of the diapausing blastocyst in a wild population of tammar wallabies Macropus eugenii. Journal of Endocrinology 95 293-300.

Gemmell RT 1991 Effect of the presence of females on plasma testosterone concentration of male marsupial bandicoots, Isoodon macrourus, housed in enclosures. General and Comparative Endocrinology 83 458-462.

Gilmore DP 1969 Seasonal reproductive periodicity in the male Australian brush-tailed possum (Trichosurus vulpecula). Journal of Zoology 157 75-98.

Goeritz F, Quest M, Wagener A, Fassbender M, Broich A, Hildebrandt TB, Hofmann RR \& Blottner S 2003 Seasonal timing of sperm production in roe deer: interrelationship among changes in ejaculate parameters, morphology and function of testis and accessory glands. Theriogenology 59 1487-1502.

Gullberg A, Olsson M \& Tegelstrom H 1997 Male mating success, reproductive success and multiple paternity in a natural population of sand lizards: behavioural and molecular genetics data. Molecular Ecology 6 105-112.

Hamilton RA, Stanton PG, O'Donnell L, Steele VR, Taggart DA \& Temple Smith PD 2000 Determination of seasonality in southern hairy-nosed wombats (Lasiorhinus latifrons) by analysis of fecal androgens. Biology of Reproduction 63 526-531.

Harcourt AH, Harvey PH, Larson SG \& Short RV 1981 Testis weight, body weight and breeding system in primates. Nature 293 55-57.

Hearn JP 1975 The role of the pituitary in the reproduction of the male tammar wallaby, Macropus eugenii. Journal of Reproduction and Fertility 42 399-402.

Hoffmann K 1973 The influence of photoperiod and melatonin on testis size, body weight, and pelage colour in the Djungarian hamster (Phodopus sungorus). Journal of Comparative Physiology $85267-282$.

Holloway JC \& Geiser F 1996 Reproductive status and torpor of the marsupial Sminthopsis crassicaudata: effect of photoperiod. Journal of Thermal Biology $21373-380$.

Hopwood D 1990 Fixation and fixatives. In Theory and Practice of Histological Techniques, edn 3, pp 21-42. Eds JD Bancroft \& A Stevens. Melbourne: Churchill Livingstone.

Huck UW \& Banks EM 1982 Male dominance status, female choice and mating success in the brown lemming, Lemmus trimucronatus. Animal Behavior 30 665-675.

Huck UW, Tonias BA \& Lisk RD 1989 The effectiveness of competitive male inseminations in golden hamsters, Mesocricetus auratus, depends on an interaction of mating order, time delay between males, and the time of mating relative to ovulation. Animal Behavior 37 674-680. 
Hughes RL, Thomson JA \& Owen WH 1965 Reproduction in natural populations of the Australian ringtail possum, Pseudocheirus peregrinus (Marsupialia: Phalangeridae), in Victoria. Australian Journal of Zoology 13 383-406.

Hynes E, Rudd CD, Temple-Smith PD, Sofronidis G, Paris DBBP, Shaw G \& Renfree MB 2005 Mating sequence, dominance and paternity success in captive male tammar wallabies. Reproduction $130123-130$.

Illius AW, Haynes NB \& Lamming GE 1976 Effects of ewe proximity on peripheral plasma testosterone levels and behaviour in the ram. Journal of Reproduction and Fertility 48 25-32.

Inns RW 1982 Seasonal changes in the accessory reproductive system and plasma testosterone levels of the male tammar wallaby, Macropus eugenii, in the wild. Journal of Reproduction and Fertility 66 675-680.

Jackson LM \& Harder JD 1996 Vomeronasal organ removal blocks pheromonal induction of estrus in gray short-tailed opossums (Monodelphis domestica). Biology of Reproduction 54 506-512.

Jainudeen MR, Katongole CB \& Short RV 1972 Plasma testosterone levels in relation to musth and sexual activity in the male Asiatic elephant, Elephas maximus. Journal of Reproduction and Fertility 29 99-103.

Jones RC 1989 Reproduction in male Macropodidae. In Kangaroos, Wallabies and Rat-Kangaroos, pp 287-305. Eds G Grigg, P Jarman, I Hume. Chipping Norton: Surrey Beatty \& Sons Pty. Limited.

Jones RC, Hinds LA \& Tyndale-Biscoe CH 1984 Ultrastructure of the epididymis of the tammar, Macropus eugenii, and its relationship to sperm maturation. Cell and Tissue Research 237 525-535.

Jones RC, Stone GM, Hinds LA \& Setchell BP 1988 Distribution of $5 \alpha$-reductase in the epididymis of the tammar wallaby (Macropus eugenii) and dependence of the epididymis on systemic testosterone and luminal fluids from the testis. Journal of Reproduction and Fertility $83779-783$.

Kamel F, Mock EJ, Wright WW \& Frankel Al 1975 Alterations in plasma concentrations of testosterone, $\mathrm{LH}$, and prolactin associated with mating in the male rat. Hormones and Behavior 6 277-283.

Katongole CB, Naftolin F \& Short RV 1971 Relationship between blood levels of luteinizing hormone and testosterone in bulls and the effects of social stimulation. Journal of Endocrinology $\mathbf{5 0}$ 457-466.

Kenagy GJ \& Trombulak SC 1986 Size and function of mammalian testes in relation to body size. Journal of Mammalogy 67 1-22.

Lincoln GA 1978 Plasma testosterone profiles in male macropodid marsupials. Journal of Endocrinology 77 347-351.

Lincoln GA \& Short RV 1980 Seasonal breeding: nature's contraceptive. Recent Progress in Hormone Research 36 1-52.

McConnell SJ, Fletcher TP \& Ellendorff F 1984 The effect of olfactory bulbectomy on plasma testosterone levels in male tammar wallabies (Macropus eugenii) exposed to females undergoing an oestrous cycle. The Australian Mammal Society Bulletin 8143.

Mickelsen WD, Paisley LG \& Dahmen JJ 1981 The effect of season on the scrotal circumference and sperm motility and morphology in rams. Theriogenology $\mathbf{1 6} 45-51$.

Monfort SL, Brown JL, Bush M, Wood TC, Wemmer C, Vargas A, Williamson LR, Montali RJ \& Wildt DE 1993 Circannual inter-relationships among reproductive hormones, gross morphometry, behaviour, ejaculate characteristics and testicular histology in Eld's deer stags (Cervus eldi thamin). Journal of Reproduction and Fertility 98 471-480.

Murdoch RN \& Jones RC 1998 The metabolic properties of spermatozoa from the epididymis of the tammar wallaby, Macropus eugenii. Molecular Reproduction and Development 49 92-99.

Nogueira JC 1988 Anatomical aspects and biometry of the male genital system of the white-belly opossum Didelphis albiventris Lund 1841 during the annual reproductive cycle. Mammalia 52 233-242.
Paris DBBP, Taggart DA, Paris MCJ, Temple-Smith PD \& Renfree MB 2004 Sperm transport, the size of the seminal plug and the timing of ovulation after natural mating in the female tammar wallaby, Macropus eugenii. Reproduction, Fertility and Development $\mathbf{1 6}$ $811-822$.

Paris DBBP, Taggart DA, Shaw G, Temple-Smith PD \& Renfree MB 2005 Birth of pouch young after artificial insemination in the tammar wallaby (Macropus eugenii). Biology of Reproduction 72 451-459.

Pizzari T, Cornwallis CK, Levlie H, Jakobson S \& Birkhead TR 2003 Sophisticated sperm allocation in male fowl. Nature 426 70-74.

Preston BT, Stevenson IR, Pemberton JM \& Wilson K 2001 Dominant rams lose out by sperm depletion. Nature 409 681-682.

Queiroz GF \& Nogueira JC 1992 Duration of the cycle of the seminiferous epithelium and quantitative histology of the testis of the South American white-belly opossum (Didelphis albiventris), Marsupialia. Reproduction, Fertility and Development 4 213-222.

Quinn GP \& Keough MJ 2002 In Experimental Design and Data Analysis for Biologists. Cambridge: Cambridge University Press.

Renfree MB \& Tyndale-Biscoe CH 1973 Intrauterine development after diapause in the marsupial Macropus eugenii. Developmental Biology 32 28-40.

Renfree MB, Fletcher TP, Blanden DR, Lewis PR, Shaw G, Gordon K, Short RV, Parer-Cook E \& Parer D 1989 Physiological and behavioural events around the time of birth in macropodid marsupials. In Kangaroos, Wallabies and Rat-Kangaroos, pp 323-337. Eds G Grigg, P Jarman, I Hume. Chipping Norton: Surrey Beatty and Sons Pty. Limited.

Rodger JC \& Hughes RL 1973 Studies of the accessory glands of male marsupials. Australian Journal of Zoology 21 303-320.

Rodger JC \& White IG 1975 Electroejaculation of Australian marsupials and analyses of the sugars in the seminal plasma from three macropod species. Journal of Reproduction and Fertility 43 $233-239$.

Rodger JC \& White IG 1978 The collection, handling and some properties of marsupial semen. Symposium of the Zoological Society 43 289-301.

Rudd, CD 1994a Sex differences in the tammar wallaby, Macropus eugenii. PhD Thesis, Monash University, Melbourne, Australia.

Rudd CD 1994b Sexual behaviour of male and female tammar wallabies (Macropus eugenii) at post-partum oestrus. Journal of Zoology $232151-162$.

Sadleir RMFS 1965 Reproduction in two species of kangaroo, Macropus robustus and Megaleia rufa in the arid Pilbara region of Western Australia. Proceedings of the Zoological Society of London 145 239-261.

Smith RFC 1969 Studies on the marsupial glider, Schoinobates volans (Kerr). I. Reproduction. Australian Journal of Zoology 17 625-636.

Smith JF, Parr J, Murray GR, McDonald RM \& Lee RSF 1999 Seasonal changes in the protein content and composition of ram seminal plasma. Proceedings of the New Zealand Society of Animal Production $59223-225$.

Swanson W, Brown J \& Wildt D 1996 Influence of seasonality on reproductive traits of the male pallas cat (Felis manul) and implications for captive management. Journal of Zoo and Wildlife Medicine 27 234-240.

Taggart DA, Selwood L \& Temple Smith PD 1997 Sperm production, storage, and the synchronization of male and female reproductive cycles in the iteroparous, stripe-faced dunnart (Sminthopsis macroura; Marsupialia): Relationship to reproductive strategies within the Dasyuridae. Journal of Zoology 243 $725-736$.

Taggart DA, Breed WG, Temple-Smith PD, Purvis A \& Shimmin GA 1998 Reproduction, mating strategies and sperm competition in marsupials and monotremes. In Sperm Competition and Sexual Selection, pp 623-666. Eds TR Birkhead \& AP Moller. London: Academic Press.

Taggart DA, Shimmin GA, Ratcliffe JR, Steele V, Dibben R, Dibben J, White C \& Temple-Smith PD 2005 Seasonal changes in the testis, 
accessory glands and ejaculate characteristics of the Southern hairy-nosed wombat, Lasiorhinus latifrons (Marsupialia:Vombatidae). Journal of Zoology 266 95-104.

Todhunter R \& Gemmell RT 1987 Seasonal changes in the reproductive tract of the male marsupial bandicoot, Isoodon macrourus. Journal of Anatomy 154 173-186.

Tyndale-Biscoe CH \& Rodger JC 1978 Differential transport of spermatozoa into the two sides of the genital tract of a monovular marsupial, the tammar wallaby (Macropus eugenii). Journal of Reproduction and Fertility 52 37-43.

Tyndale-Biscoe CH \& Renfree MB 1987 In Reproductive Physiology of Marsupials. Cambridge: Cambridge University Press.

Tyndale-Biscoe CH, Hearn JP \& Renfree MB 1974 Control of reproduction in macropodid marsupials. Journal of Endocrinology $\mathbf{6 3}$ 589-614.

Ward SJ \& Renfree MB 1988 Reproduction in males of the feathertail glider Acrobates pygmaeus Marsupialia. Journal of Zoology 216 $241-252$.
Westneat DF, McGraw LA, Fraterrigo JM, Birkhead TR \& Fletcher F 1998 Patterns of courtship behavior and ejaculate characteristics in male red-winged blackbirds. Behavioral Ecology and Sociobiology $43161-171$.

Williams SC, Fletcher TP \& Renfree MB 1998 Puberty in the female tammar wallaby. Biology of Reproduction 58 1117-1122.

Winegarner MS 1982 Seasonal changes in the reproductive tract of the male opossum Didelphis virginiana in Florida USA. American Midland Naturalist 107 258-261.

Woolley PA 1990 Reproduction in Sminthopsis macroura (Marsupialia: Dasyuridae) II. The male. Australian Journal of Zoology $\mathbf{3 8}$ 207-218.

Received 18 October 2004

First decision 29 November 2004

Revised manuscript received 27 May 2005

Accepted 6 June 2005 